\title{
CORRELATION ANALYSIS OF BRANDS IN THE HUNGARIAN NEW TRACTOR MARKET
}

\author{
Author(s): \\ V. Medina - R. Tóth - M. Daróczi - Á. Bak
}

Affiliation:

Engineering Management Institute, Szent István University, Páter K. street. 1., Gödöllö, H-2100, Hungary

Email address:

medina.viktor@gek.szie.hu, toth.reka@gek.szie.hu, daroczi.miklos@gek.szie.hu, bak.arpad@gek.szie.hu,

\begin{abstract}
There are many tractor brands in Hungary. We examined whether are there any correlation among them. We set up a hypothesis that there is certain seasonality in the new tractor market in Hungary. We supposed also that the subsidies have a strong effect on the seasonality. For this reason we analysed the correlation of the nine most sold tractor brands in our paper. The research covers six years database and almost 100 thousand data. Based on the study we can declare certain seasonality in the new tractor market, which is influenced very much by the impact of state supports for investment. Although the whole tractor market has seasonality, the brands have a different correlation, because of the different marketing strategies of the brands.
\end{abstract}

\section{Keywords}

tractor brands, tractor market, correlation analysis, impact of support, Hungary

\section{Introduction}

The agriculture plays an important role in Hungary. Its competitiveness is determined by the level of the agricultural machinery $[1,2]$ The subsidies for investments can strengthen the competitiveness of the Hungarian agricultural sector [3]. For this reason the production is influenced very much by the supports. Presently the support system for investments is unpredictable. The producers aren't able to plan for long time, but the $35-45 \%$ subsidy is so high, the growers want to buy new machinery to utilize the EU money for reducing their costs.

Based on our hypothesis the tractor market can be characterized with seasonality. The sales have similar tendencies in every year. This market rhythm is usually disturbed by the supports for buying machines. The goal of our examination is to verify the hypothesis of the tractor market's seasonality and to show the effects of the subsidies.

\section{Methods}

The examination is based on the KEK KH data, which was collected, systemised and filtered by Datahouse Ltd. The data series from 2009 until 2014 was submitted by the Hungarian Association of Agricultural Tool and Machinery Distributors
(MEGFOSZ). We elaborated the sheets containing almost 100 thousand data and systematized by brands to be able to analyse the correlations between the years.

It is expedient to typify the correlation between two variables with an index-number [4]. There are many such index-numbers, but the most popular is the Pearson correlation coefficient, which measures the tightness of the linear relation among the measurements. The coefficient is signed by $r$, its value is always between -1 and 1 . If the points aren't situated along a linear, there isn't any correlation $(\mathrm{r}=0)$ or the correlation is weak (the value of $r$ is closed to 0 ) If the points are situated along a linear $r$ is closed to 1 or -1 , in this case there is a strong correlation. If the points are directly on an increasing linear $\mathrm{r}=1$, if on a decreasing linear $\mathrm{r}=-1$. The correlation coefficient is symmetric, the two variables are commutable [4]. The weakness of the Pearson coefficient is that it isn't permitted to use it for part average, because it could show stronger relation than in deed.

If our data is measured not on interval scale but ordinal, then we can use the Spearman correlation coefficient. Its value is always between 1 and -1 . The value 1 shows a perfect conformity between the $X_{i}$ and $Y_{i}$ rank number series. The value -1 means the two series are converse. If it is 0 there isn't any relation between the two rank series [5].

The Kendall's correlation coefficient is the alternative for Spearmann index to measure the correlation between two variables. To calculate it we use the natural order of the variables rank numbers. Its value is between 1 and -1 . The meaning of the values is the same as in the case of Spearmann index. The calculation of spearman and Kendall coefficient is different, but the values are similar. Usually the Spearmann's coefficient shows more correlation than the Kendall's one [6,7].

We used these three coefficients to verify and show the relation among years, brands and sales tendencies. The calculations were made by SPSS.

\section{Results}

The examination of the whole database with Pearson correlation coefficient shows significant correlation in some cases. The years 2009 and 2013 have value 0,687 , the signification level value is 0,014 , which is similar than the relation of years $2010 / 2013$ and $2011 / 2012$. The years $2011 / 2012$ have a little less correlation, but with a signification level still below 0,05 (Table 1.). It was interesting the relation of the years 2009/2012, because the value 
is 0,000 with a signification level 0,999 . This means a completely independency. The year 2014 has a small negative correlation with the years 2009, 2010, 2013, although this correlation is not significant.

Table 1. Pearson correlation for the total tractor market

\begin{tabular}{|c|c|c|c|c|c|c|c|}
\hline & 2009 & 2010 & 2011 & 2012 & 2013 & 2014 \\
\hline \multirow[t]{2}{*}{2009} & Pearson Correlation & 1 &, 380 &, 518 &, 000 &, $687^{*}$ &,- 393 \\
\hline & Sig. (2-tailed) & & ,223 & 085 & ,999 &, 014 & 206 \\
\hline \multirow[t]{2}{*}{2010} & Pearson Correlation & ,380 & 1 & 196 &, 323 & ,682* &,- 267 \\
\hline & Sig. (2-tailed) & ,223 & &, 542 &, 306 &, 014 & ,401 \\
\hline \multirow[t]{2}{*}{2011} & Pearson Correlation &, 518 & 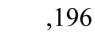 & 1 & $693^{*}$ & $653^{*}$ & ,181 \\
\hline & Sig. (2-tailed) & 085 &, 542 & & ,012 & ,021 &, 574 \\
\hline \multirow[t]{2}{*}{2012} & Pearson Correlation &, 000 & ,323 & ,693 & 1 & 393 & ,415 \\
\hline & Sig. (2-tailed) & ,999 & ,306 & 012 & & ,206 & , 180 \\
\hline \multirow[t]{2}{*}{2013} & Pearson Correlation & ,687 & ,682* & ,653 & ,393 & 1 &,- 118 \\
\hline & Sig. (2-tailed) & ,014 & ,014 & ,021 & 206 & &, 715 \\
\hline \multirow[t]{2}{*}{2014} & Pearson Correlation &,- 393 &,- 267 & ,181 & ,415 &,- 118 & 1 \\
\hline & Sig. (2-tailed) & 206 & ,401 &, 574 & 180 &, 715 & \\
\hline
\end{tabular}

* Correlation is significant at the 0.05 level (2-tailed).

Calculations are based on KEKKH, Datahouse and MEGFOSZ data

The results of Kendall's correlation coefficient show an even stronger correlation at the year pairs 2009/2013, 2011/2012, 2011/2013. Comparing with the results of Pearson coefficient there was no significant the relation in the years 2010/2013. In the other cases there was even stronger correlation. The signification level decreased below 0,010. The values of Spearman's coefficient show even stronger correlation (Table 2). The main diverse value comes from 2014, because the correlation has negative value in four years.

Table 2. Kendall and Spearmann coefficient for the total tractor market

\begin{tabular}{|c|c|c|c|c|c|c|c|c|}
\hline & & & 2009 & 2010 & 2011 & 2012 & 2013 & 2014 \\
\hline \multirow[t]{12}{*}{$\begin{array}{l}\text { Kendall's } \\
\text { tau_b }\end{array}$} & \multirow[t]{2}{*}{2009} & $\begin{array}{l}\text { Correlation } \\
\text { Coefficient }\end{array}$ & \multirow[t]{2}{*}{1,000} & ,273 & ,273 & , 107 &, $576^{* *}$ &,- 242 \\
\hline & & Sig. (2-tailed) & & ,217 & ,217 & 630 & ,009 & ,273 \\
\hline & \multirow[t]{2}{*}{2010} & $\begin{array}{l}\text { Correlation } \\
\text { Coefficient }\end{array}$ & ,273 & 1,000 &, 030 & ,229 & ,333 &,- 182 \\
\hline & & Sig. (2-tailed) & ,217 & & 891 & ,303 & ,131 & ,411 \\
\hline & \multirow[t]{2}{*}{2011} & $\begin{array}{l}\text { Correlation } \\
\text { Coefficient }\end{array}$ & ,273 & ,030 & 1,000 &, $595^{* *}$ &, $576^{* *}$ &,- 121 \\
\hline & & Sig. (2-tailed) & ,217 & 891 & &, 007 & ,009 &, 583 \\
\hline & \multirow[t]{2}{*}{2012} & $\begin{array}{l}\text { Correlation } \\
\text { Coefficient }\end{array}$ & , 107, & ,229 &, $595^{* *}$ & 1,000 & ,473" & , 168 \\
\hline & & Sig. (2-tailed) & ,630 & ,303 & ,007 & & ,033 &, 450 \\
\hline & \multirow[t]{2}{*}{2013} & $\begin{array}{l}\text { Correlation } \\
\text { Coefficient }\end{array}$ &, $576^{* *}$ & ,333 &, $576^{* *}$ &, $473^{*}$ & 1,000 &,- 061 \\
\hline & & Sig. (2-tailed) & , 009 & ,131 & ,009 & ,033 & & ,784 \\
\hline & \multirow[t]{2}{*}{2014} & $\begin{array}{l}\text { Correlation } \\
\text { Coefficient }\end{array}$ &,- 242 &,- 182 &,- 121 & , 168 &,- 061 & 1,000 \\
\hline & & Sig. (2-tailed) & ,273 & ,411 &, 583 & ,450 &, 784 & \\
\hline \multirow[t]{12}{*}{$\begin{array}{l}\text { Spearman' } \\
\text { s rho }\end{array}$} & \multirow[t]{2}{*}{2009} & $\begin{array}{l}\text { Correlation } \\
\text { Coefficient }\end{array}$ & 1,000 & ,448 & ,462 & ,214 &, $755^{* *}$ &,- 364 \\
\hline & & Sig. (2-tailed) & & ,145 & ,131 &, 505 & ,005 & ,245 \\
\hline & \multirow[t]{2}{*}{2010} & $\begin{array}{l}\text { Correlation } \\
\text { Coefficient }\end{array}$ & ,448 & 1,000 & , 126 & ,322 & ,524 &,- 182 \\
\hline & & Sig. (2-tailed) &, 145 & & ,697 & ,307 & ,080 &, 572 \\
\hline & \multirow[t]{2}{*}{2011} & $\begin{array}{l}\text { Correlation } \\
\text { Coefficient }\end{array}$ & ,462 & , 126 & 1,000 &, $725^{* * *}$ &, $755^{* *}$ &,- 133 \\
\hline & & Sig. (2-tailed) & ,131 & 697 & & ,008 &, 005 & ,681 \\
\hline & \multirow[t]{2}{*}{2012} & $\begin{array}{l}\text { Correlation } \\
\text { Coefficient }\end{array}$ & ,214 & ,322 &, $725^{* *}$ & 1,000 & ,673* & ,287 \\
\hline & & Sig. (2-tailed) &, 505 & ,307 & ,008 & & ,017 &, 365 \\
\hline & \multirow[t]{2}{*}{2013} & $\begin{array}{l}\text { Correlation } \\
\text { Coefficient }\end{array}$ &, $755^{* *}$ &, 524 &, $755^{* *}$ & $673^{*}$ & 1,000 &,- 098 \\
\hline & & Sig. (2-tailed) & ,005 & ,080 & ,005 &, 017 & &, 762 \\
\hline & \multirow[t]{2}{*}{2014} & $\begin{array}{l}\text { Correlation } \\
\text { Coefficient }\end{array}$ &,- 364 &,- 182 &,- 133 & ,287 &,- 098 & 1,000 \\
\hline & & Sig. (2-tailed) & ,245 &, 572 & ,681 & 365 &, 762 & \\
\hline
\end{tabular}

**. Correlation is significant at the 0.01 level (2-tailed).

*. Correlation is significant at the 0.05 level (2-tailed).

Calculations are based on KEK KH, Datahouse and MEGFOSZ data 
The examination of the whole database results a strong correlation among the years 2011, 2012 and 2013. In these three years we can see seasonality and there wasn't any impact of the subsidies. In 2009 was a support for buying agricultural machines to compensate the world crisis in 2008. In 2010 there was a very strong drop on the tractor market. This decline can explain the weaker correlation of the year 2010 with the others. In 2013 it was announced again a subsidy, which had an effect in 2014. This impact is manifested in the correlation coefficients, also with its negative values in previous years.
We made also the correlation analysis of 9 tractor brands. The results show some variation. The main similarity between global and brand seasonality we could see in the case of the year 2014, where the small negative correlation with 2009, 2010, 2011, 2013 was shown in almost all brands. The correlation between 2011 and 2013 was declared in the case of Case, Fendt, John Deere and New Holland. In the other cases were different correlations among the years (Table 3 ).

Table 3. Spearmann coefficient in the case of different tractor brands

\begin{tabular}{|l|c|c|c|c|c|c|c|c|c|c|c|c|}
\hline Brand & Year & Coeff. & Sig. & Year & Coeff. & Sig. & Year & Coeff. & Sig. & Year & Coeff. & Sig. \\
\hline Case & $2009 / 2010$ & 0,584 & 0,046 & $2010 / 2011$ & 0,739 & 0,006 & $2010 / 2013$ & 0,722 & 0,008 & $2011 / 2013$ & 0,898 & 0,000 \\
\hline Claas & $2011 / 2014$ & 0,614 & 0,034 & $2012 / 2013$ & 0,611 & 0,035 & $2013 / 2014$ & 0,648 & 0,023 & - & - & - \\
\hline Fendt & $2011 / 2013$ & 0,504 & 0,046 & $2012 / 2013$ & 0,609 & 0,035 & $2012 / 2013$ & 0,609 & 0,035 & - & - & - \\
\hline $\begin{array}{l}\text { John } \\
\text { Deere }\end{array}$ & $2009 / 2010$ & 0,74 & 0,006 & $2011 / 2013$ & 0,71 & 0,01 & $2012 / 2014$ & 0,582 & 0,047 & - & - & - \\
\hline MTZ & $2009 / 2010$ & 0,757 & 0,004 & $2009 / 2013$ & 0,643 & 0,024 & $2010 / 2013$ & 0,839 & 0,001 & $2012 / 2013$ & 0,643 & 0,024 \\
\hline $\begin{array}{l}\text { New } \\
\text { Holland }\end{array}$ & $2010 / 2012$ & 0,578 & 0,049 & $2011 / 2013$ & $-0,711$ & 0,01 & $2013 / 2014$ & 0,747 & 0,005 & - & - & - \\
\hline
\end{tabular}

Calculations are based on KEK KH, Datahouse and MEGFOSZ data

Analysing the correlation between years at different brands we can declare that the significant correlations are very variable in different years and brands. There were also three brands, where we couldn't find any relation between the years. The sales had no seasonality in the case of Landini, Massey Ferguson and Zetor.

\section{Conclusion}

Summarizing the results we can conclude that there is certain seasonality in the new tractor market, which is influenced very much by the impact of investment state supports. The years 2011, 2012, 2013 have significant correlation each other. These years were not disturbed by the subsidies. The years 2009, 2010 and 2014 have no correlations with other years because of the great influence of state supports. These clear relationships were not found in the case of brand examinations. The examined nine brands had different correlation in different years. This fact shows the effect of the different marketing activity of the brands. There is a variance between the global and brand seasonality. The different marketing strategies result varying intensity of sales and explain the deviations.

\section{Acknowledgments}

This publication is a result of a research work performed in the project called: TÁMOP-4.2.1.D-15/1/KONV-2015-0007 Smart City: Innovatív kutatási hálózatok fejlesztése Gyula és Salgótarján városokban.

\section{References}

[1.] Magó L.: 2008a. A gépkihasználás fokozásával megvaló sítható alacsony költségủ gépesítési megoldások különböző üzemi méretű növénytermelő gazdaságokban, in Szerk.: Takács István „Müszaki fejlesztési támogatások közgazdasági hatékonyságának mérése" c. tanulmánykötet, Szent István Egyetemi Kiadó Gödöllö, p. 213-228., p. 244.

[2.] Magó L.: 2008b. Low Cost Mechanisation for Efficient Land Use in Small and Medium Size Arable Farms, Cereal Research Communications, Akadémiai Kiadó, Vol. 36: p. 1111-1114.

[3.] Magó L.: 2000. Relationship Between Farm Machine Requirement and Farm Size, Gazdálkodás, Scientific Journal on Agricultural Economics - English special edition Vol. XLIV., No. 1., p. 66-75.

[4.] Anderson D.: 1998. Statistics for Business and Economics, 7th edition, USA, South Western College Publishing, ISBN 0538875933

[5.] Flemming M. C. Nellis J. G. (1996): The Essence of Statistics for Business, 2nd edition, Hemel Hempstead, UK, Prentice Hall Europe, ISBN 013987779

[6.] Levin R, Rubin D. (1997): Statistics for Management, 7th edition, Englewood Clifs, NJ: Prentice Hall International, ISBN 0136067166

[7.] Vincze I., Varbanova M. (1993): Nemparaméteres matematikai statisztika, Akadémiai Kiadó, 